\title{
Pengembangan instrumen supervisi akademik dalam penerapan pembelajaran berdiferensiasi
}

\author{
Nunuk Hariyati ${ }^{1 *}$, Karwanto ${ }^{2}$, Amrozi Khamidi ${ }^{3}$, Ainur Rifqi ${ }^{4}$ \\ ${ }^{1}$ Universitas Negeri Surabaya, Surabaya, Indonesia, email: nunukhariyati@unesa.ac.id \\ ${ }^{2}$ Universitas Negeri Surabaya, Surabaya, Indonesia, email: karwanto@unesa.ac.id \\ ${ }^{3}$ Universitas Negeri Surabaya, Surabaya, Indonesia, email: Amrozi110@gmail.com \\ ${ }^{4}$ Universitas Negeri Surabaya, Surabaya, Indonesia, email: ainurrifqi@unesa.ac.id \\ *Koresponden penulis
}

\section{Info Artikel}

Diajukan: 2021-10-09

Diterima: 2021-11-28

Diterbitkan: 2021-12-21

Keywords:

instrument development; academic supervision; differentiated learning

Kata Kunci:

pengembangan instrument; supervisi akademik; pembelajaran

berdiferensiasi

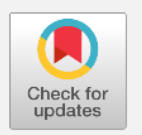

(i) (2)

Lisensi: $c c-b y$-sa

Copyright @ Nunuk Hariyati, Karwanto, Amrozi Khamidi, Ainur Rifqi

\begin{abstract}
Merdeka Belajar was introduced by Kementerian Pendidikan dan Kebudayaan as a form of transformation of education management that places students' well-being as the main orientation in learning activities. Differentiated learning becomes an alternative learning model that can realize students' well-being. As a supervisor, the principal plays an important role in improving the quality of learning through academic supervision activities. Developing academic supervision instruments in differentiated learning is one of the important efforts that can realize students' well-being and support Merdeka Belajar Policy. situation analysis in Nganjuk Regency, indicated: (1) differentiated learning was not yet known in detail by the teacher, (2) the academic supervision instrument in differentiated learning had not been developed by the principal. This community service activity aims to increase knowledge and develop supervision instruments in differentiated learning. The training method is through expository learning, online assignments, mentoring, and FGD (Focus Group Discussion) which are attended by 54 Principals who are members of the MKKS. The results showed that there was an increase in the average pro-test to the pre-test by $20 \%$. In addition, assignments to school principals are very effective to improving skills in preparing academic supervision instruments in the application of differentiated learning.
\end{abstract}

Abstrak
Kebijakan Merdeka Belajar digulirkan Kementerian Pendidikan dan
Kebudayaan sebagai wujud transformasi pengelolaan pendidikan
yang menempatkan well-being peserta didik sebagai orientasi utama
dalam kegiatan pembelajaran. Pembelajaran berdiferensiasi menjadi
alternatif model pembelajaran yang mampu mewujudkan well-being
bagi peserta didik. Sebagai seorang supervisor, Kepala Sekolah
berperan penting dalam meningkatkan kualitas pembelajaran melalui
kegiatan supervisi akademik. Pengembangan instrumen supervisi
akademik yang mengarah pada pembelajaran berdiferensiasi menjadi
salah satu upaya penting yang dapat mewujudkan well-being peserta
didik sekaligus mendukung Kebijakan Merdeka Belajar. Analisis
situasi di Kabupaten Nganjuk menghasilkan informasi: (1)
pembelajaran berdiferensiasi belum diketahui secara detail oleh guru,
(2) instrumen supervisi akademik dalam pembelajaran berdiferensiasi
belum dikembangkan oleh kepala sekolah. Sehingga tujuan
pengabdian kepada masyarakat ini adalah untuk meningkatkan
pengetahuan dan mengembangkan instrumen supervisi dalam
pembelajaran berdiferensiasi. Metode pelatihan yaitu melalui


pendekatan ekspositori, pembimbingan, penugasan dan FGD (Focus Group Discussion) yang diikuti 54 Kepala Sekolah yang tergabung dalam MKKS. Hasil penelitian menunjukkan bahwa terjadi peningkatan rata-rata pro-test terhadap pre-test yaitu sebesar $20 \%$. Selain itu penugasan terhadap kepala sekolah menjadi sangat efektif dalam meningkatkan keterampilan menyusun instrumen supervisi akademik dalam penerapan pembelajaran berdiferensiasi.

Cara mensitasi artikel:

Hariyati, N., Karwanto, Khamidi, A., \& Rifqi, A. (2022). Pengembangan instrumen supervisi akademik dalam penerapan pembelajaran berdiferensiasi. Jurnal Inovasi Hasil Pengabdian Masyarakat (JIPEMAS), 5(1), 33-44. https://doi.org/10.33474/jipemas.v5i1.13605

\section{PENDAHULUAN}

Kebijakan Merdeka Belajar digulirkan Kementerian Pendidikan dan Kebudayaan (Kemdikbud) pada tahun 2019 sebagai wujud transformasi pengelolaan pendidikan yang berorientasi pada tercapainya well-being peserta didik. Salah satu program pemerintah yang mendukung kebijakan Merdeka Belajar adalah Program Sekolah Penggerak yaitu sebuah program yang berfokus pada pengembangan hasil belajar siswa secara holistik dengan mewujudkan profil pelajar Pancasila. Proses transformasi yang dikembangkan dalam program sekolah penggerak adalah pembelajaran yang dapat menyediakan suasana belajar yang aman, nyaman, inklusif, dan menyenangkan serta berpusat pada siswa sehingga dapat mencapai hasil belajar di atas level yang diharapkan (Kemendikbud, 2021). Salah satu intervensi pemerintah dalam melaksanakan program sekolah penggerak adalah menerapkan pembelajaran dengan paradigma baru yaitu pembelajaran yang dirancang dengan prinsip pembelajaran terdiferensiasi sehingga siswa belajar sesuai dengan kebutuhan dan tahap perkembangannya.

Pembelajaran berdiferensiasi dikemukakan Tomlinson (2001) sebagai sebagai konsep pembelajaran yang tepat untuk mewujudkan well-being peserta didik karena diimplementasikan melalui pemetaan kebutuhan peserta didik yang diintegrasikan dalam proses pembelajaran sehingga sangat mendukung implementasi program sekolah penggerak yang berorientasi pada siswa. Implementasi program sekolah penggerak harus diawali dengan sumber daya manusia (SDM) yang unggul yaitu kepala sekolah dan guru. Kepala sekolah sebagai pemegang kekuasaan tertinggi memiliki peran yang sangat penting untuk mendukung terlaksananya pembelajaran berdiferensiasi. Kepala sekolah diharuskan memiliki kemampuan dalam memimpin dengan berorientasi pada model kepemimpinan instruksional (Kemendikbud, 2021). Kepemimpinan instruksional merupakan kepemimpinan yang memusatkan tujuan pada pengembangan pembelajaran dan salah satu tindakannya adakah supervisi akademik (Day et al., 2016; Glickman, 1985). Sebagai seorang supervisor, kepala sekolah bertanggungjawab membantu meningkatkan profesionalitas guru dalam kegiatan pembelajaran (Ali, 2019). Supervisi akademik merupakan salah satu bentuk kegiatan pengawasan serta pembinaan yang dilakukan kepala sekolah kepada guru dengan tujuan mendorong guru untuk lebih berdaya, menjadikan pengajaran lebih efektif, dan tercapainya tujuan pembelajaran (Kemdikbud RI, 2019). 
Kepala sekolah berperan sangat penting terhadap kelangsungan pembelajaran yang harmonis, nyaman dan dapat membawa kesejahteraan bagi peserta didik dalam kondisi apapun khususnya dalam pemenuhan kebutuhan belajar yang berbeda-beda. Peran supervisor kepala sekolah sangat mendukung pengembangan pelaksanaan pembelajaran berdiferensiasi yang efektif dan efisien. Hal tersebut didasarkan pada definisi supervisi akademik yang merupakan konsep bersifat kontekstual dan multidimensional yang mampu berkontribusi positif terhadap kualitas pembelajaran apabila dilaksanakan dengan tepat sesuai konteks dan kebutuhan guru dalam proses pembelajaran (Gordon, 2019; Hariyati, 2020). Supervisi akademik diimplementasikan melalui aktivitas yang berfokus pada pemberian bantuan dengan tujuan meningkatkan profesionalitas guru (Glickman et al., 2013). Secara lebih mendalam Sergiovanni (1982) mengemukakan bahwa supervisi akademik selain untuk membantu meningkatkan kemampuan profesional, juga difungsikan untuk memeriksa dan memastikan pembelajaran di sekolah terlaksana sesuai dengan ketentuan dan tujuan sehingga akan mendorong guru untuk meningkatkan kompetensi, melaksanakan tugas dengan sepenuh hati dan memiliki komitmen yang tinggi sebagai guru. Sehingga demikian mengartikulasikan bahwa melalui aktivitas supervisi, kepala sekolah berkontribusi dalam memonitor proses belajar mengajar serta mendorong guru untuk memaksimalkan kemampuan yang meningkatkan profesionalitasnya (Sergiovanni, 1987).

Konsep supervisi akademik sangat sesuai dalam menunjang implementasi pembelajaran berdiferensiasi yang bertujuan mencapai wellbeing peserta didik. Well-being peserta didik merupakan interpretasi dari kesehatan fisik, mental dan dimensi-dimensi lain yang menjadikan peserta didik merasa nyaman, bermakna, dan menyenangkan dalam kegiatan pembelajaran (Nelson et al., 2015; Soutter et al., 2014). Well-being peserta didik menjadi indikator yang memberikan gambaran keefektifan peserta didik dalam menerima proses pembelajaran (Fraillon, 2004). Secara fisik, well-being dicirikan dengan sikap dan emosi yang positif terhadap sekolah serta akademik yang baik (Hidayah et al., 2016). Well-being pada peserta didik dalam proses pembelajaran tidak hanya menyangkut kemampuan akademik, melainkan juga pada kondisi dimana peserta didik benar-benar merasa sejahtera (Muhammad \& Rosiana, 2019). Pollard \& Lee Karyani et al. (2015) menyempurnakan ciri well-being pada peserta didik dalam lima dimensi yakni (1) kognitif ditandai melalui prestasi akademik yang baik; (2) fisik ditandai melalui kesehatan serta kebugaran fisik; (3) psikologis yang ditandai melalui kepuasan hidup; (4) sosial yang ditandai dengan hubungan yang harmonis dengan orangtua, teman sebaya dan masyarakat.

Konsep well-being mengejawantahkan keharusan bagi sekolah sebagai lembaga penyelenggaraan pendidikan untuk mampu mengelola proses pembelajaran efektif yang mendukung terwujudnya well-being pada peserta didik. Proses pembelajaran menjadi faktor utama yang dapat mempengaruhi kesuksesan sekolah (Leithwood et al., 2020). Dengan demikian kepala sekolah 
memiliki kewajiban untuk memastikan pembelajaran terlaksana dengan baik dan mencapai kesejahteraan.

Pembelajaran yang sesuai dalam mendukung konsep well-being adalah pembelajaran berdiferensiasi sebagaimana dikemukakan Tomlinson (2001) bahwa pembelajaran berdiferensiasi merupakan pembelajaran yang dapat mengakomodir kebutuhan belajar peserta didik dengan mengidentifikasi dan memetakan kebutuhan peserta didik sesuai kesiapan, minat, dan profil belajar peserta didik yang dituangkan melalui konten, proses dan produk pembelajaran. Pembelajaran berdiferensiasi berorientasi pada perbedaan kebutuhan pembelajaran peserta didik (Amin, 2009) dan cenderung pada pembelajaran yang mengakomodir kebutuhan belajar melalui strategi pembelajaran yang independen (Marlina, 2019). Berdasarkan kajian tersebut diketahui bahwa pembelajaran berdiferensiasi memiliki pengaruh kuat dalam mewujudkan pembelajaran yang mencapai well-being. Sebagai supervisor, kepala sekolah dapat mewujudkan pembelajaran berdiferensiasi yang efektif dengan mengembangkan instrumen supervisi akademik yang memperhatikan unsur-unsur pembelajaran berdiferensiasi.

Berdasarkan hasil studi pendahuluan diketahui bahwa Kabupaten Nganjuk merupakan salah satu wilayah dalam Provinsi Jawa Timur yang memiliki 54 Sekolah Menengah Pertama (SMP) berstatus negeri dan hasil analisis situasi di Kabupaten Nganjuk diperoleh informasi bahwa (1) sebagian besar guru SMP Negeri di Kabupaten Nganjuk belum mengetahui dan memahami secara mendalam tentang ruang lingkup dan implementasi pembelajaran berdiferensiasi, (2) secara keseluruhan kepala sekolah belum menguasai dan belum pernah mengembangkan instrumen supervisi akademik yang mendukung terlaksananya pembelajaran berdiferensiasi.

Atas dasar permasalahan yang ditemui di Kabupaten Nganjuk, tim pengabdian kepada masyarakat melaksanakan pengabdian kepada masyarakat yang berjudul pelatihan pengembangan instrumen supervisi akademik dalam penerapan pembelajaran berdiferensiasi pada kepala SMP Negeri di Kabupaten Nganjuk. Pelatihan tersebut bertujuan meningkatkan derajat pengetahuan dan kompetensi kepala sekolah dalam mengembangkan instrumen supervisi akademik yang mendukung terlaksananya pembelajaran berdiferensiasi. Tujuan berkelanjutan dari pelatihan tersebut adalah meningkatkan pemahaman guru tentang pelaksanaan pembelajaran berdiferensiasi yang mampu mencapai well-being peserta didik.

\section{METODE PELAKSANAAN}

Metode pelaksanaan yang digunakan untuk mendukung terealisasinya pelatihan ini adalah ToT (Training of Trainer) yang diuraikan dalam beberapa kegiatan sebagai berikut.

\section{Penyampaian materi}

Penyampaian materi dengan menerapkan pendekatan ekspositori yaitu menekankan pada penyampaian materi secara verbal dengan tujuan peserta dapat menguasai materi pelatihan secara konseptual (Killen, 1998). Model ini sangat penting dilaksanakan secara luring dengan 
harapan dapat membangun pemahaman secara konseptual tentang ruang lingkup pembelajaran berdiferensiasi, dan supervisi akademik termasuk langkah-langkah penyusunan instrumen supervisi akademik pada pembelajaran berdiferensiasi. Pendekatan ekspositori merupakan pendekatan yang berorientasi pada pemateri sehingga dalam pendekatan ini pemateri memegang peran yang sangat dominan. Pendekatan ekspositori bertujuan mentransferkan pengetahuan, keterampilan dan nilainilai kepada objek sasaran (Safriadi, 2017).

\section{Diskusi dan tanya jawab}

Penyampaian materi ditindaklanjuti dengan kegiatan diskusi dan tanya jawab dengan tujuan menemukan permasalahan dan memberikan solusi yang diimplementasikan secara aktif dua arah.

\section{Penugasan}

Penugasan diberikan dengan tujuan mengetahui sejauhmana hasil penyampaian materi dan diskusi dapat dipahami oleh peserta.

\section{Bimbingan dan Diskusi}

Pada proses penugasan dilakukan pembimbingan dan diskusi bersama tim yang merupakan ahli di bidang supervisi. Pada tahap bimbingan peserta diperkenankan secara aktif untuk berdiskusi untuk meningkatkan pemahaman.

\section{Evaluasi dan feedback}

Hasil penugasan ditindak lanjuti dengan melakukan evaluasi guna mengetahui peningkatan kemampuan peserta dan memberikan feedback berupa saran dan masukan yang membangun.

\section{HASIL DAN PEMBAHASAN}

Pelaksanaan PkM yang dilaksanakan di SMK PGRI 1 Nganjuk dengan melibatkan Pemerintah Kabupaten Nganjuk yaitu Musyawarah Kerja Kepala Sekolah (MKKS) berjalan efektif dan memberikan hasil yang signifikan. Pelatihan dilaksanakan dengan konsep luring dan daring. Pelatihan secara luring melaksanakan kegiatan penyampaian materi, diskusi dan tanya jawab. Peserta pelatihan seharusnya berjumlah 54 orang yang merupakan seluruh kepala sekolah SMP Negeri di Kabupaten Nganjuk. Namun dikarenakan pandemi, pelatihan dibatasi hanya 16 peserta dengan mematuhi protokol kesehatan. Pelaksanaan pelatihan secara luring diawali dengan apersepsi untuk membangun motivasi kepada peserta pelatihan yang kemudian dilanjutkan dengan pengisian pre-test. Pre-test diberikan dengan tujuan mengetahui tingkat pemahaman peserta pelatihan terkait materi yang akan disajikan. Berdasarkan hasil analisis terhadap nilai pre-test diperoleh data kemampuan peserta dengan rata-rata sebesar 34,68 dari skor maksimal 60 . Kesimpulan terhadap hasil analisis diketahui bahwa sebagian besar peserta pelatihan belum mengetahui secara mendalam tentang konsep dan pelaksanaan pembelajaran berdiferensiasi, sedangkan untuk konsep supervisi secara umum telah dipahami namun peserta menyatakan bahwa belum mampu menyusun instrumen supervisi yang efektif untuk meningkatkan profesionalitas guru dalam mewujudkan pembelajaran berdiferensiasi yang berkualitas. 
Setelah pengisian pre-test, pelatihan dilaksanakan dengan penyajian materi. Adapun materi dan alokasi waktu yang digunakan dalam pelatihan disajikan melalui tabel berikut.

Tabel 1. Materi dan alokasi waktu pelatihan

\begin{tabular}{lcc}
\hline \multicolumn{1}{c}{ Materi } & Luring (JP) & Daring (JP) \\
\hline Perencanaan Supervisi & 1 & 3 \\
Pelaksanaan Supervisi & 1 & 3 \\
Rencana Tindak Lanjut Supervisi & 1 & 3 \\
Pembelajaran Berdiferensiasi & 1 & 2 \\
Penyusunan Instrumen Supervisi pada & 1 & 16 \\
Pembelajaran Berdiferensiasi & & \\
\hline
\end{tabular}

Materi pelatihan disajikan oleh tim PkM yang merupakan ahli bidang supervisi pendidikan dan ahli bidang inti eksistensi manajemen pendidikan. Pelatihan secara luring dilaksanakan dengan pendekatan ekspositori sebanyak 5 JP secara synchronous dengan bantuan media power point. Materi perencanaan supervisi disajikan dengan tujuan menyegarkan kembali pengetahuan peserta tentang langkah-langkah perencanaan supervisi yang efektif. Begitupun materi selanjutnya yaitu pelaksanaan supervisi dan rencana tindak lanjut supervisi. Karena secara umum peserta adalah kepala sekolah, materi tentang ruang lingkup supervisi telah dikuasai dan pemateri hanya menyegarkan kembali dan memperdalam wawasan peserta tentang konsep tersebut. Dokumentasi penyajian materi sebagai berikut.

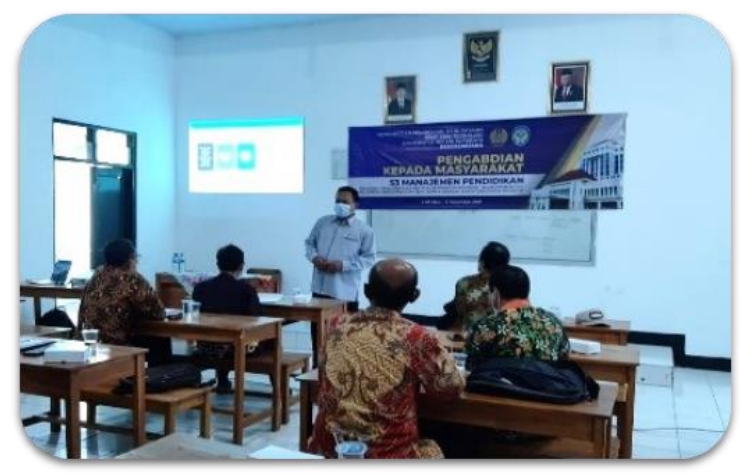

Gambar 1. Metode ekspositori

Penyajian materi dilanjutkan dengan mengulas secara mendalam tentang ruang lingkup pembelajaran berdiferensiasi dan disajikan contoh penyusunan instrumen supervisi akademik. Dokumentasi penyajian materi pembelajaran berdiferensiasi adalah sebagai berikut. 


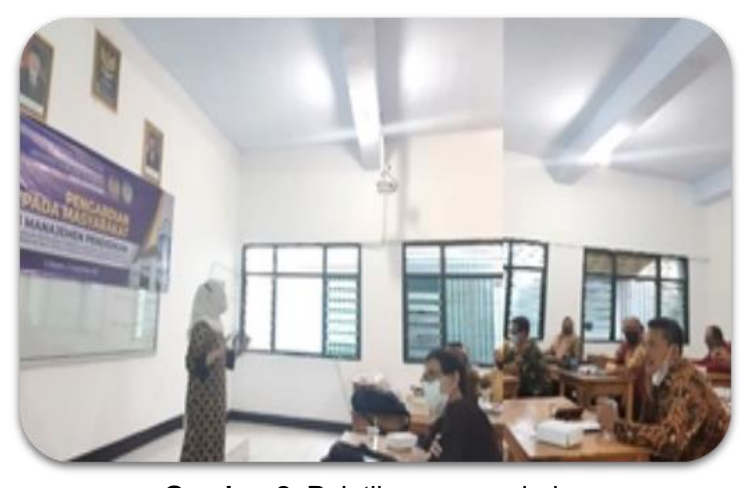

Gambar 2. Pelatihan secara luring

Pelatihan secara luring dilanjutkan dengan pelatihan secara daring. Kegiatan pelatihan yang dilakukan secara daring meliputi penugasan, bimbingan dan diskusi, serta evaluasi dan feedback. Penugasan dilakukan dengan pemberian contoh form instrumen supervisi akademik untuk dikembangkan kepala sekolah sebagaimana yang dicontohkan pada saat penyampaian materi secara luring. Matriks penugasan ditunjukkan seperti berikut.

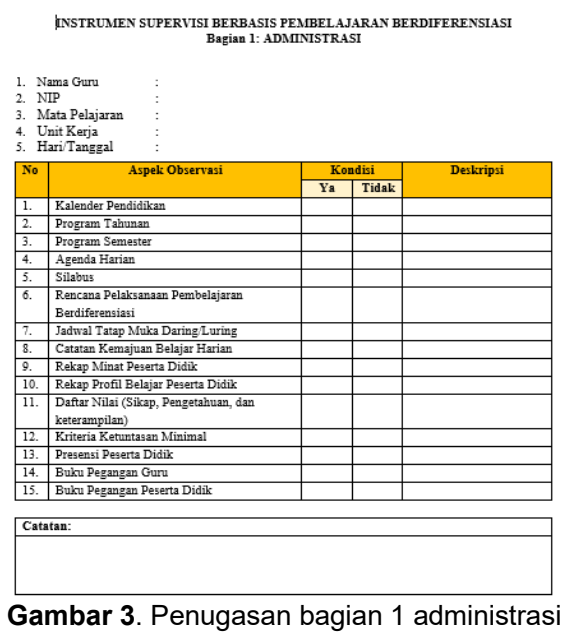

Pada lembar instrumen administrasi peserta dibimbing untuk mampu mengidentifikasi dokumen-dokumen administrasi yang mencirikan pembelajaran berdiferensiasi sehingga membangun pengetahuan secara konkrit tentang apa saja kebutuhan yang harus disiapkan dalam implementasi pembelajaran berdiferensiasi. 

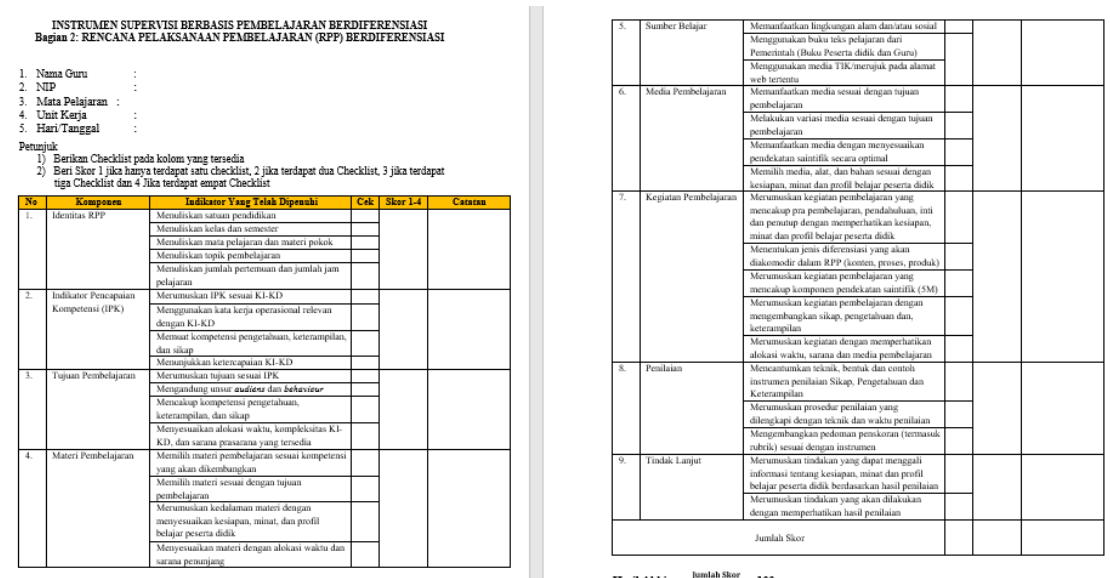

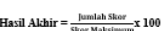

Gambar 4. Penugasan bagian 2 RPP berdiferensiasi

Pada lembar instrumen RPP (Rencana Pelaksanaan Pembelajaran) peserta diarahkan untuk mampu mengidentifikasi poin-poin yang menunjukkan karakteristik diferensiasi konten dalam pembelajaran berdiferensiasi. Penugasan berikutnya adalah penyusunan instrumen pelaksanaan. Pada lembar ini peserta dibimbing untuk menyusun instrumen yang mampu mengidentifikasi karakteristik diferensiasi proses dalam pembelajaran. Lembar yang dimaksud ditunjukkan sebagai berikut.
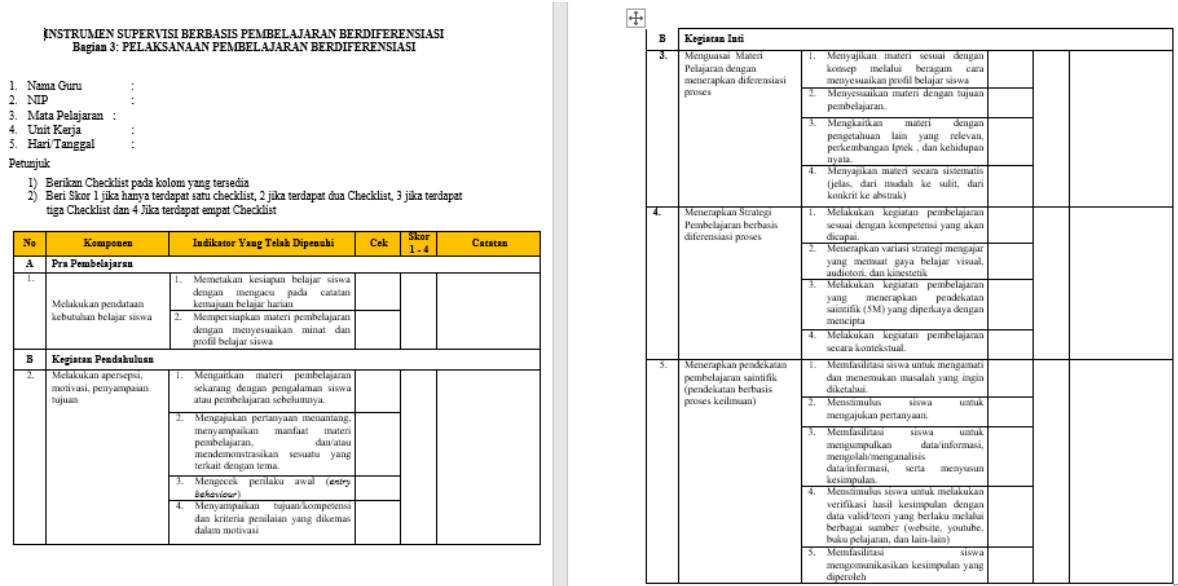

Gambar 5. Penugasan bagian 3 pelaksanaan pembelajaran berdiferensiasi

Penugasan yang terakhir adalah penyusunan instrumen penilaian. Sebagaimana dalam konsep pembelajaran berdiferensiasi, pada lembar ini peserta dibimbing untuk mampu menyusun instrumen yang dapat memotret diferensiasi produk pembelajaran. Sehingga pada akhirnya penugasan ini membantu kepala sekolah menyusun instrumen supervisi akademik dalam konsep pembelajaran berdiferensiasi secara konkrit. Matriks instrumen penilaian adalah sebagai berikut. 

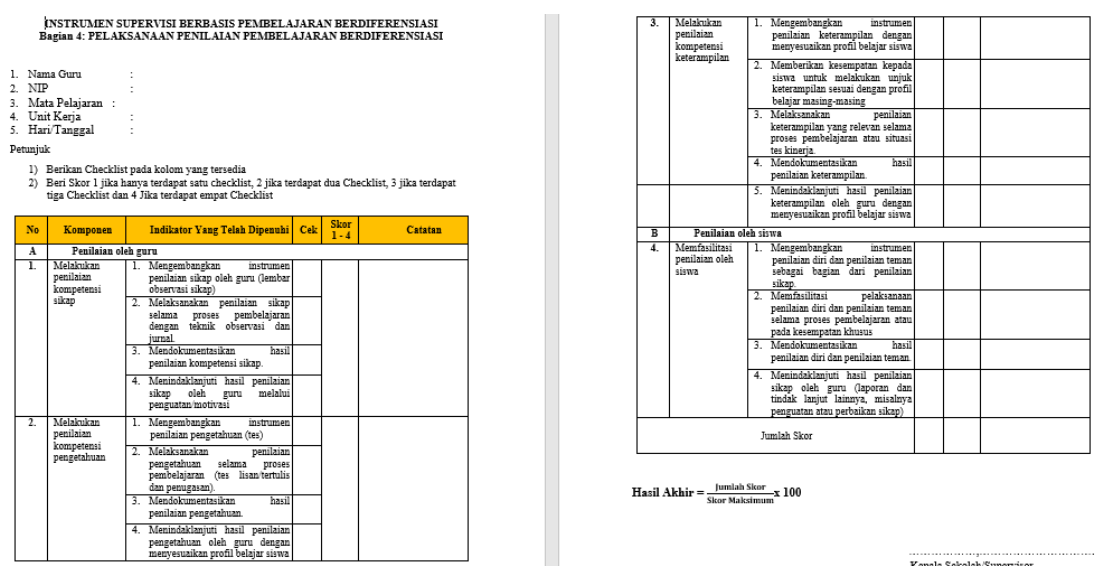

Hasil Akhir $=\frac{\text { Iumanh Slar }}{\text { Sllor Malsismum }} 100$

Gambar 6. Penugasan bagian 4 penilaian

Penugasan pengembangan instrumen merupakan alternatif penugasan yang tepat karena instrumen merupakan suatu alat yang dapat digunakan supervisor dalam mengidentifikasi kemampuan guru dalam melaksanakan pembelajaran (Hartanto \& Purwanto, 2019).

Pembimbingan dilaksanakan dengan konsultasi pada pemateri melalui FGD dengan tujuan mewujudkan pelatihan yang interaktif, yaitu terjalin saling diskusi antar peserta dalam menyelesaikan penugasan. FGD menjadi metode yang sangat tepat dalam pelatihan sebagaimana hasil penelitian Bisjoe (2018) bahwa FGD dapat memberikan informasi yang mendalam, bernilai dan hemat biaya. FGD mengandung tiga kunci yaitu diskusi, kelompok, dan terfokus (Siregar \& Safitri, 2019). Proses diskusi berjalan aktif yang dilaksanakan dengan saling bertukar pendapat, berbagi pengalaman, memberi saran dan tanggapan dengan peserta lain yang satu profesi. Dokumentasi proses pembimbingan dan diskusi melalui media zoom disajikan pada gambar 9 berikut.

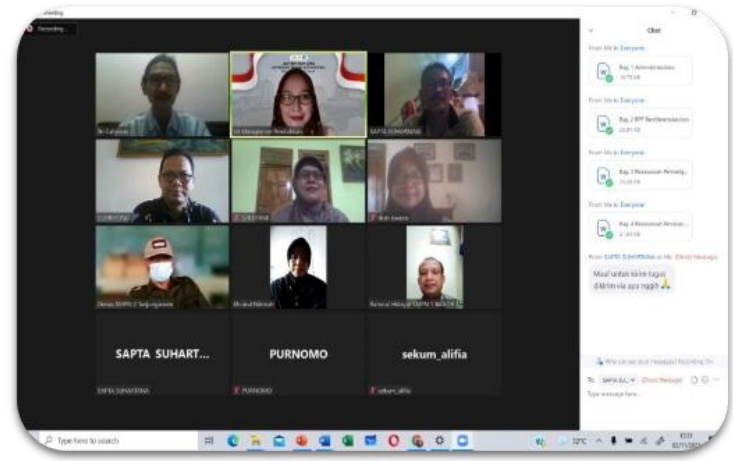

Gambar 7. Bimbingan dan diskusi melalui aplikasi zoom

Pembimbingan dilaksanakan dengan diskusi yakni kepala sekolah memperoleh pengalaman dan pengetahuan dari permasalahan yang ditemui dalam menyusun instrumen supervisi. Pelaksanaan pembimbingan dan FGD 
menunjukkan respon yang aktif sehingga menggambarkan terjadinya proses berpikir dan peningkatan pengetahuan.

Proses evaluasi yang dilakukan oleh tim memperoleh hasil terhadap penugasan yang menunjukkan bahwa $90 \%$ peserta telah mampu menyusun secara lengkap instrumen supervisi akademik dan memenuhi unsur-unsur pembelajaran berdiferensiasi yaitu diferensiasi konten, proses, dan produk yang meninjau pada kesiapan, minat dan profil belajar siswa. Hasil penugasan selaras dengan hasil peningkatan post-test terhadap pre-test. Hasil post-test memperoleh rata-rata sebesar 46,7 dari skor maksimal 60. Sehingga menunjukkan kenaikan skor rata-rata dari skor 34,68 menjadi 46,7 atau sebesar $20 \%$. Grafik kenaikan ditunjukkan pada gambar berikut.

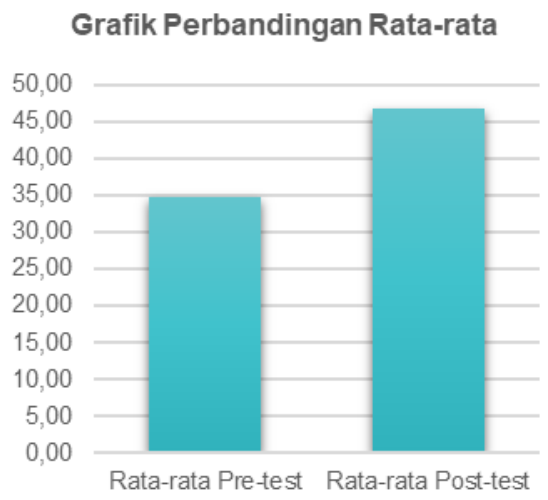

Gambar 8. Grafik Perbandingan Pre-test dan Post-test

Berdasarkan grafik perbandingan, jumlah peserta kemudian diklasifikasikan berdasarkan tingkat pemahaman materi dan penugasan. Adapun secara rinci jumlah peserta dalam persen berdasarkan nilai pre-test dan post-test disajikan dalam tabel 2 berikut.

Tabel 2. Jumlah Peserta dalam Persen Berdasarkan Nilai Pre-test dan Post-test

\begin{tabular}{lcccc}
\hline \multirow{2}{*}{ Kategori } & \multicolumn{2}{c}{ Pre-test } & \multicolumn{2}{c}{ Post-test } \\
\cline { 2 - 5 } & Jumlah Peserta & Persentase & Jumlah Peserta & Persentase \\
\hline Sangat tidak memahami & 0 & $0 \%$ & 0 & $0 \%$ \\
Tidak memahami & 2 & $4 \%$ & 0 & $0 \%$ \\
Cukup memahami & 31 & $57 \%$ & 4 & $7 \%$ \\
Memahami & 21 & $39 \%$ & 29 & $54 \%$ \\
Sangat memahami & 0 & $0 \%$ & 21 & $39 \%$ \\
\hline
\end{tabular}

Tabel 2 menunjukkan bahwa terjadi perubahan jumlah peserta yang dikategorikan dari hasil pre-test dan post-test. Persentase peserta yang terkategori tidak memahami semula sebesar $4 \%$ menurun menjadi $0 \%$. Artinya sudah tidak ada peserta yang tidak memahami tentang konsep supervisi dan pembelajaran berdiferensiasi. Sedangkan jumlah peserta yang memahami meningkat dari $39 \%$ menjadi $54 \%$. Peningkatan persentase juga terjadi pada kategori sangat memahami yaitu dari $0 \%$ menjadi $39 \%$. Hasil tersebut mengartikulasikan terjadi peningkatan pengetahuan peserta tentang ruang lingkup supervisi akademik dan pembelajaran berdiferensiasi. Tindak lanjut 
yang dilaksanakan oleh tim adalah pemberian feedback terhadap seluruh hasil penugasan yang telah diselesaikan oleh peserta. Dengan demikian pelatihan penyusunan instrumen supervisi akademik dalam pembelajaran berdiferensiasi efektif dalam meningkatkan pengetahuan dan keterampilan kepala sekolah sebagai peserta pelatihan dalam kegiatan pengabdian kepada masyarakat. Namun keterbatasan PkM ini adalah belum mencapai tahapan uji coba instrumen sehingga efektivitas instrumen yang disusun belum diketahui.

\section{KESIMPULAN}

Berdasarkan hasil pelaksanaan pengabdian kepada masyarakat dapat disimpulkan bahwa peserta mampu menyusun instrumen supervisi pembelajaran berdiferensiasi dan mampu memahami konsep serta pentingnya pembelajaran berdiferensiasi. Sehingga pelatihan ini berkontribusi dalam meningkatkan kemampuan kepala sekolah dalam mendukung terlaksananya program sekolah penggerak yang melaksanakan pembelajaran berpusat pada siswa. Berdasarkan keterbatasan pelaksanaan PkM, saran yang dapat diajukan guna meningkatkan kualitas pelaksanaan pelatihan yang relevan adalah instrumen dapat diuji cobakan dalam kegiatan supervisi di sekolah masingmasing kemudian dilakukan evaluasi efektifitas dari instrumen tersebut.

\section{DAFTAR RUJUKAN}

Ali, J. H. (2019). Peran Kepala Sekolah Sebagai Supervisor dalam Meningkatkan Mutu Pembelajaran Guru Mata Pelajaran IPA Pada SDN Roja 1 Ende. Jurnal Dinamika Sains, 3(1), 50-56. https://ejournal.uniflor.ac.id/index.php/optika/article/view/114

Amin. (2009). Pembelajaran Berdiferensiasi: Alternatif Pendekatan Pembelajaran Bagi Anak Berbakat. Jurnal Edukasi, 1(1), 57-67.

Bisjoe, A. R. (2018). Menjaring Data dan Informasi Penelitian Melalui FGD ( Focus Group Discussion ): Belajar Dari Praktik Lapang. Info Teknis EBONI, 15(1), 17-28. https://doi.org/10.20886/buleboni.2018.v15.pp1727

Day, C., Gu, Q., \& Sammons, P. (2016). The Impact of Leadership on Student Oytcomes: How Succesful School Leaders Use Transformational and Instructional Strategies to Make a Difference. Educational Administration Quarterly, 1-38. https://doi.org/10.1177/0013161X15616863

Fraillon, J. (2004). Measuring student well-being in the context of Australian schooling: discussion paper. The Australian Council for Educational Research, December.

Glickman, C. D. (1985). Supervision of instruction: A developmental approach. Allyn \& Bacon.

Glickman, C. D., Gordon, S. P., \& Gordon, J. M. R. (2013). The Basic Guide to Supervision and Instructional Leadership. Pearson Education Inc.

Gordon, S. (2019). Educational Supervision: Reflections on Its Past, Present, and Future. Journal of Educational Supervision, 2(2), 27-52. https://doi.org/https://doi.org/10.31045/jes.2.2.3

Hariyati, N. (2020). Metamorfosis Supervisi Pendidikan Di Masa Pandemi 
Covid-19. In Belajar dari Covid-19: Perspektif Sosiologi, Budaya, Hukum Kebijakan \& Pendidikan (pp. 145-154). Yayasan Kita Menulis. https://kitamenulis.id/2020/07/05/belajar-dari-covid-19-perspektifsosiologi-budaya-hukum-kebijakan-dan-pendidikan/

Hartanto, S., \& Purwanto, S. (2019). Supervisi dan penilaian kinerja guru. Direktorat Pembinaan Tenaga Kependidikan, Guru Dan Tenaga Kependidikan.

Hidayah, N., Pali, M., Ramli, M., \& Hanurawan, F. (2016). Students' Well-Being Assessment at School. Journal of Educational, Health and Community Psychology, 5(1), 62-71. https://doi.org/10.12928/jehcp.v5i1.6257

Karyani, U., Prihartanti, N., Dinar, W., Lestari, R., Hertinjung, W. S., Prasetyaningrum, J., \& Yuwono, Y. (2015). The dimensions of student well-being. Seminar Psikologi \& Kemanusiaan. Psychology Forum UMM. Kemdikbud RI. (2019). Supervisi dan Pengawasan Pendidikan.

Kemendikbud. (2021). Program Sekolah Penggerak. In Kementerian Pendidikan dan Kebudayaan.

Killen, R. (1998). Effective Teaching Strategies: Lesson from Reserch and practice (2th Eds). Social Science Press.

Leithwood, K., Harris, A., \& Hopkins, D. (2020). Seven strong claims about successful school leadership revisited. School Leadership and Management, 40(1), $5-22$.

https://doi.org/10.1080/13632434.2019.1596077

Marlina, M. (2019). Panduan Pelaksanaan Model Pembelajaran Berdiferensiasi di Sekolah Inklusif.

Muhammad, F., \& Rosiana, D. (2019). Student Well-Being pada Siswa MTs X Cimahi.

Nelson, M. D., Tarabochia, D. W., \& Koltz, R. L. (2015). PACES: A Model of Student Well-Being. Journal of School Counseling, 13(19).

Safriadi. (2017). Prosedur Pelaksanaan Strategi Pembelajaran. Jurnal MUDARRISUNA: Media Kajian Pendidikan Agama Islam, 7(1), 47-65. https://doi.org/10.22373/jm.v7i1.1908

Sergiovanni. (1987). Educational Governance and Administration. Prentice Hall Inc.

Sergiovanni, T. J. (1982). Supervision of Teaching. Alexandria: Association for Supervision and Curriculum Development.

Siregar, N. Y., \& Safitri, T. A. (2019). Pengaruh Pengungkapan Enterprise Risk Management, Intellectual Capital, Corporate Social Responsibility, dan Sustainability. Jurnal Bisnis Darmajaya, 5(2), 53-79. https://jurnal.darmajaya.ac.id/index.php/JurnalBisnis/article/view/1589

Soutter, A. K., O'Steen, B., \& Gilmore, A. (2014). The student well-being model: A conceptual framework for the development of student well-being indicators. International Journal of Adolescence and Youth, 19(4), 496520. https://doi.org/10.1080/02673843.2012.754362

Tomlinson, C. A. (2001). Differentiate Instruction IN Mixed-Ability Classrooms Differentiate Instruction. Association for Supervision and Curriculum Development. 